\title{
Quality Changes and Discoloration of Basa (Pangasius bocourti) Fillet during Frozen Storage
}

\author{
Pornpimol Sriket $\mathbb{D}^{1,2}$ and Thamarak La-ongnual ${ }^{3}$ \\ ${ }^{1}$ Program in Food Business and Nutrition, Faculty of Agriculture, Ubon Ratchathani Rajabhat University, \\ Ubon Ratchathani 34000, Thailand \\ ${ }^{2}$ Unit of Agriculture and Food Products Development, Faculty of Agriculture, Ubon Ratchathani Rajabhat University, \\ Ubon Ratchathani 34000, Thailand \\ ${ }^{3}$ Program in Fisheries, Faculty of Agriculture, Ubon Ratchathani Rajabhat University, Ubon Ratchathani 34000, Thailand
}

Correspondence should be addressed to Pornpimol Sriket; raksakantong.p@gmail.com

Received 27 April 2018; Accepted 29 August 2018; Published 23 September 2018

Academic Editor: Jorge Barros-Velázquez

Copyright (c) 2018 Pornpimol Sriket and Thamarak La-ongnual. This is an open access article distributed under the Creative Commons Attribution License, which permits unrestricted use, distribution, and reproduction in any medium, provided the original work is properly cited.

Physicochemical changes of Basa fish (Pangasius bocourti) fillet during frozen storage at $-20^{\circ} \mathrm{C}$ for $0-20$ weeks were studied. The content of thiobarbituric acid reactive substances (TBARS) of fish samples suddenly increased when the samples were stored longer than 8 weeks $(p<0.05)$. The increase in TBARS value of the fish fillet was concomitant with the increase in $b^{*}$ value (yellow color). Marked decreases in $\mathrm{Ca}^{2+}$-ATPase activity, sulfhydryl content, and protein solubility of the fish fillet after 8 weeks of storage were observed. Those decreasing values were well correlated with the increasing of disulfide bond content and surface hydrophobicity content $(p<0.05)$. Increases in shear force of fish meat during storage were also observed $(p<0.05)$. The results indicated that frozen storage at $-20^{\circ} \mathrm{C}$ affected on Basa fillet qualities, especially after 8 weeks of storage. These data could be useful for consumer and food industry.

\section{Introduction}

Basa, (Pangasius bocourti) a freshwater fish, has been increasingly produced and consumed due to its taste and useful nutrients. Vietnam is the largest producer of catfish such as Basa and Sawai (Pangasius hypophthalmus), followed by Thailand, Cambodia, Lao People's Democratic Republic, Myanmar, Bangladesh, and China [1]. In Thailand, Basa is promoted to be cultured in areas along the Mae Khong shore of Thailand [2]. It is generally processed to frozen fillets for domestic consumption and also exported to Europe and USA. Recently, the market of the frozen catfish fillet has been increasing due to its desirable qualities such as easily digestible protein [3]. Frozen seafood products are imperative since fish products are one of the most highly traded food commodities [4]. Freezing is a means to prevent fish quality deterioration during transportation, storage, retail display, or consumption. The deterioration caused by microbial and enzyme activity can be limited effectively under frozen storage [5]. However, discoloration and destruction of texture caused by the denaturation of proteins and lipid oxidation still occurred during frozen storage $[6,7]$.

The deterioration of fish meat during frozen storage depends on many factors such as fish species, storage temperature, time, and enzymatic degradation $[8,9]$. Denaturation and aggregation of muscle proteins during frozen storage are associated with the formation of disulfide and the interaction of lipid oxidation products with proteins [4]. Denaturation induced by frozen storage contributed to the decrease in the protein solubility of fish meat. The oxidation of lipid also takes place easily and limits the shelf life of fish during frozen storage [7]. Lipid oxidation is of great concern to the food industries and consumers since it contributes to the development of poor color, odor, and texture as well as reduced nutritional value $[10,11]$. Our preliminary study shows that Basa meat contained high levels of unsaturated 
fatty acids and that it is very susceptible to oxidation. The lipid components of postmortem fish muscle tissue are prone to oxidation because fatty acids of fish lipids are much more unsaturated than those of mammals and birds [12]. Quality changes and muscle discoloration related to lipid oxidation of some fish species have been reported $[7,13,14]$. However, no information regarding physicochemical changes, lipid oxidation, and discoloration in muscle of Basa fish cultured in Thailand during frozen storage has been reported. Therefore, the objective of this research was to investigate the quality changes, lipid oxidation, and discoloration of Basa fish during frozen storage.

\section{Materials and Methods}

2.1. Chemicals. Ammonium molybdate, 5-5'-dithio-bis (2-nitrobenzoic acid) (DTNB), adenosine $5^{\prime}$ - triphosphate (ATP), $p$-nitrophenyl- $\alpha$-glucopyranoside, $p$-nitrophenyl-Nacetyl- $\beta$-D-glucose amide, 1 -anilinonaphthalene-8-sulphonic acid (ANS), thiobarbituric acid (TBA), and malondialdehyde (MDA) were purchased from Sigma (St. Louis, MO, USA). Potassium chloride $(\mathrm{KCl})$ and urea were obtained from Ajax Finechem (Wellington, New Zealand). All chemicals were of analytical grade.

2.2. Sample Preparation. Basa (P. bocourti) weighing $2 \mathrm{~kg}$, killed by ice-shocking, were purchased from the fish farm in Ubon Ratchathani, Thailand. The fish were kept in ice using a fish/ice ratio of $1: 2(\mathrm{w} / \mathrm{w})$ during transportation to the Program in Food Business and Nutrition, Faculty of Agriculture, Ubon Ratchathani Rajabhat University, Ubon Ratchathani province. Upon arrival, the fish were washed with tap water, filleted, and deskinned. Fish fillets were packed in a polyethylene bag. The samples were frozen by air-blast freezer and kept at $-20^{\circ} \mathrm{C}$ for different times $(0,4,8$, 12,16 , and 20 weeks). At the time designated, frozen fish were thawed using running tap water $\left(25-27^{\circ} \mathrm{C}\right)$, until the core temperature reached $0-2^{\circ} \mathrm{C}$. The thawed samples were then subjected to analyses.

\subsection{Determination of Thiobarbituric Acid Reactive Substances} (TBARS). TBARS were determined as described by Buege and Aust [15]. Fish paste (2g), containing various concentrations of iron, was dispersed in $10 \mathrm{~mL}$ of thiobarbituric acid solution $(0.375 \%$ thiobarbituric acid, $15 \%$ trichloroacetic acid, and $0.25 \mathrm{~N} \mathrm{HCl}$ ). The mixture was heated in boiling water for 10 minutes, followed by cooling in running tap water. The mixture was centrifuged at $3600 \times \mathrm{g}$ for 20 minutes at room temperature. The absorbance of the supernatant was measured at $532 \mathrm{~nm}$ using a spectrophotometer (Model UV 1800, Shimadzu, Kyoto, Japan). The standard curve was prepared using malondialdehyde, and TBARS values were expressed as $\mathrm{mg}$ malondialdehyde $/ \mathrm{kg}$ samples.

2.4. Determination of Color. The color of the fish fillet was measured using a colorimeter (Color Flex, Hunter Lab Inc., Reston, VA, USA) and reported in the CIE color profile system as $L^{*}, a^{*}$, and $b^{*}$ values.
2.5. Determination of Surface Hydrophobicity. Surface hydrophobicity (SoANS) was determined as described by Benjakul et al. [16] using 1-anilinonaphthalene-8-sulfonic acid (ANS) as a probe. Natural actomyosin (NAM) was prepared as described by Benjakul et al. [16]. NAM solution $(4 \mathrm{mg} / \mathrm{mL})$ was diluted in $10 \mathrm{mM}$ phosphate buffer, $\mathrm{pH} 6.0$, containing $0.6 \mathrm{M} \mathrm{NaCl}$ to produce protein concentrations of $0.125,0.25,0.5$, and $1 \mathrm{mg} / \mathrm{mL}$, followed by incubation at room temperature for $10 \mathrm{~min}$. The diluted protein solution $(2 \mathrm{~mL})$ was mixed with $20 \mu \mathrm{L}$ of $8 \mathrm{mM}$ ANS in $0.1 \mathrm{M}$ phosphate buffer, $\mathrm{pH}$ 7.0, and the fluorescence intensity of ANSconjugates was immediately measured using a spectrofluorometer (RF-15001, Shimadzu, Kyoto, Japan) at an excitation wavelength of $374 \mathrm{~nm}$ and an emission wavelength of $485 \mathrm{~nm}$. The initial slope of the plot of fluorescence intensity versus protein concentration was referred to as SoANS.

2.6. Determination of Total Sulfhydryl Content. The total sulfhydryl content was determined using 5,5' -dithio-bis (2nitrobenzoic acid) (DTNB) according to the method of Ellman [17] as modified by Benjakul et al. [16]. NAM was prepared as described by Benjakul et al. [16]. One milliliter of NAM solution $(4 \mathrm{mg} / \mathrm{mL})$ was mixed with $9 \mathrm{~mL}$ of $0.2 \mathrm{M}$ Tris- $\mathrm{HCl}$ buffer, $\mathrm{pH} 6.8$, containing $8 \mathrm{M}$ urea, $2 \%$ SDS, and $10 \mathrm{mM}$ EDTA. Four $\mathrm{mL}$ of the mixture was mixed with $0.4 \mathrm{~mL}$ of $0.1 \% \mathrm{DTNB}$ and incubated at $40^{\circ} \mathrm{C}$ for $25 \mathrm{~min}$. The absorbance at $412 \mathrm{~nm}$ was measured using a spectrophotometer, and a $0.6 \mathrm{M} \mathrm{KCl}$ solution was used as a blank. The sulfhydryl content was calculated using the extinction coefficient of $13500 \mathrm{M}^{-1} \cdot \mathrm{cm}^{-1}$.

2.7. Determination of Disulfide Bond Content. The disulfide bond content was determined using the 2-nitro-5thiosulfobenzoate (NTSB) assay according to the method of Thannhauser et al. [18]. NAM was prepared as described by Benjakul et al. [16]. To $0.5 \mathrm{~mL}$ of NAM solution $(4 \mathrm{mg} / \mathrm{mL})$, $3.0 \mathrm{~mL}$ of freshly prepared NTSB assay solution was added. The mixture was mixed thoroughly and incubated in dark at room temperature for $25 \mathrm{~min}$. The absorbance at $412 \mathrm{~nm}$ was measured using a spectrophotometer. The disulfide bond content was calculated using the extinction coefficient of $13900 \mathrm{M}^{-1} \cdot \mathrm{cm}^{-1}$.

2.8. Determination of $\mathrm{Ca}^{2+}$-ATPase Activity. ATPase activity was determined by using the method of Benjakul et al. [16]. NAM was diluted to $3-5 \mathrm{mg} / \mathrm{mL}$ with $0.6 \mathrm{M} \mathrm{KCl}, \mathrm{pH}$ 7.0. The diluted NAM solution $(0.5 \mathrm{~mL})$ was added to $0.3 \mathrm{~mL}$ of $0.5 \mathrm{M}$ Tris-maleate, $\mathrm{pH}$ 7.0. The mixture was treated with $0.5 \mathrm{~mL}$ of $10 \mathrm{mM} \mathrm{CaCl}_{2}$ and $3.45 \mathrm{~mL}$ of distilled water. To initiate the reaction, $0.25 \mathrm{~mL}$ of $20 \mathrm{mM}$ ATP was added. The reaction was conducted for $10 \mathrm{~min}$ at $25^{\circ} \mathrm{C}$ and terminated by adding $2.5 \mathrm{~mL}$ of chilled $15 \%(\mathrm{w} / \mathrm{v})$ trichloroacetic acid. The reaction mixture was centrifuged at $3500 \times \mathrm{g}$ for $5 \mathrm{~min}$, and the inorganic phosphate liberated in the supernatant was measured using the method of Fiske and Subbarow [19]. Specific activity was expressed as $\mu \mathrm{mol}$ inorganic phosphate (Pi) 
released $/ \mathrm{mg}$ protein/min. A blank solution was prepared by adding chilled trichloroacetic acid prior to addition of ATP.

2.9. Determination of Protein Solubility. Solubility was determined according to Benjakul and Bauer [20]. To $1 \mathrm{~g}$ fish meat, $20 \mathrm{~mL}$ of $0.6 \mathrm{M} \mathrm{KCl}$ was added, and the mixture was homogenized for $1 \mathrm{~min}$ at a speed of $12000 \mathrm{rpm}$, using an IKA homogenizer (IKA, Labortechnik, Selangor, Malaysia). The homogenate was stirred at $4^{\circ} \mathrm{C}$ for $4 \mathrm{~h}$, followed by centrifuging at $8500 \times \mathrm{g}$ for $30 \mathrm{~min}$ at $4^{\circ} \mathrm{C}$. To $10 \mathrm{~mL}$ of supernatant, and cold $\left(4^{\circ} \mathrm{C}\right) 50 \%(\mathrm{w} / \mathrm{v})$ trichloroacetic acid was added to obtain a final concentration of $10 \%$. The precipitate was washed with $10 \%$ trichloroacetic acid and solubilized in $0.5 \mathrm{M} \mathrm{NaOH}$. The fish meat was also directly solubilized by $0.5 \mathrm{M} \mathrm{NaOH}$ to determine total protein. The protein content was determined using the Biuret method [21] and expressed as the percentage of total protein in the sample.

2.10. Determination of Shear Force. Shear force of the Basa fillet during frozen storage was measured using the TA-XT2i texture analyzer (Stable Micro Systems, Surrey, England) equipped with a Warner-Bratzler shear apparatus [22]. The cylindrical longitudinal muscle samples of the fillet were cut out with a borer of $11 \mathrm{~mm}$ in diameter. The blade was pressed down at a constant speed of $2 \mathrm{~mm} / \mathrm{s}$ through the sample, cutting the muscle fiber transversely. Shear force $(\mathrm{N})$ was recorded from six measurements.

2.11. Statistical Analysis. Experiments were run in triplicate. Data were subjected to analysis of variance (ANOVA), and mean comparison was carried out using Duncan's multiple range test (DMRT) [23]. Statistical analyses were performed using the Statistical Package for Social Science (SPSS 13.0 for windows, SPSS Inc., Chicago, IL).

\section{Results and Discussion}

3.1. Changes in TBARS Values. Changes in TBARS values in the Basa fillet during frozen storage at $-20^{\circ} \mathrm{C}$ for 20 weeks are shown in Figure 1. TBARS values have been used to determine the secondary products of lipid oxidation, especially aldehydes and decomposition products of hydroperoxides [24]. The slight increases in TBARS values of the Basa fillet during the first 8 weeks of storage were observed (Figure 1). Thereafter, sharp increases in the TBARS values were noticeable $(p<0.05)$. TBARS values of the Basa fillet were continuously increased until the end of storage (20 weeks). The increases in TBARS values in anchovy (Engraulis encrasicholus) [25] and cuttlefish muscle [7] during frozen storage were also reported.

Increase in TBARS value of the Basa fillet was possibly due to the denaturation of fish muscle during the extended storage. Catalysts released from the denatured or disrupted muscle cells could accelerate the lipid oxidation. Lipid oxidations in fish muscle induced by frozen storage were reported $[6,7]$. The ice crystals formed during the freezing process could disrupt cells and release pro-oxidants for lipid

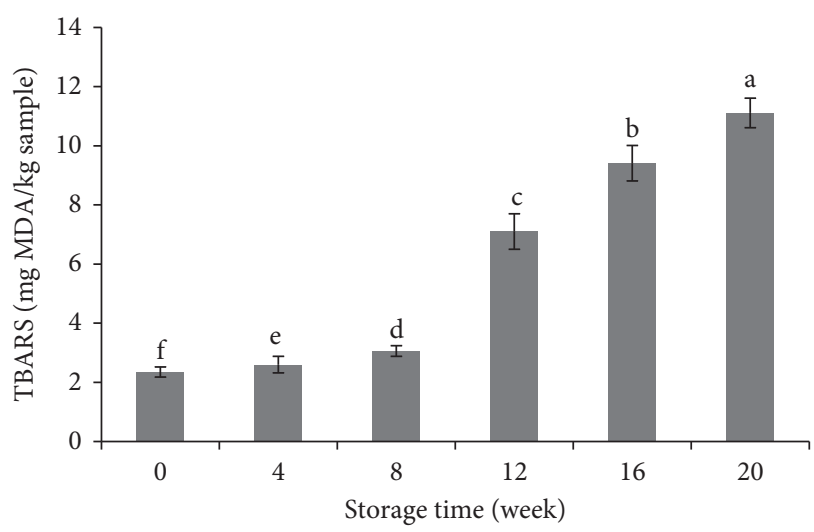

Figure 1: Changes in TBARS value of the Basa fish fillet during frozen storage at $-20^{\circ} \mathrm{C}$ for 20 weeks. Bars represent standard deviation from triplicate determinations. The different letters on the bars indicate significant differences $(p<0.05)$.

oxidation, especially free iron [26]. The free iron can act as a pro-oxidant in fish muscle and was associated with the enhanced lipid oxidation [27]. The increase of TBARS value varied with fish species, and fat content was also reported [28]. The differences in lipid oxidation possibly resulted from the different fatty acid compositions. Unsaturated fatty acids are more prone to oxidation, compared to saturated fatty acids. Our preliminary study showed that the Basa fillet had high fat content (13.26\%) and unsaturated fatty acid $(66.91 \mathrm{~g} / 100 \mathrm{~g}$ lipid). Frozen storage affected on lipid oxidation of the Basa fillet as indicated by the increase in TBARS value during storage for 20 weeks.

3.2. Changes in Color. Changes in $L^{*}$ (lightness), $a^{*}$ (redness), and $b^{*}$ (yellowness) values of the Basa fillet during frozen storage at $-20^{\circ} \mathrm{C}$ for 20 weeks are depicted in Figure 2 . There was no difference in $L^{*}, a^{*}$, and $b^{*}$ values of the Basa fillet during the first 8 weeks of storage $(p>0.05)$. However, a decrease in the $L^{*}$ values of the fish fillet was observed when the storage time increased up to 12 weeks (Figure 2). The decreased $L^{*}$ value of cuttlefish muscle during frozen storage was reported [7]. A decrease in the $a^{*}$ value in the fish fillet was observed when the samples were stored longer than 8 weeks $(p<0.05)$ (Figure 2). Pigment degradation can also lead to the changes in muscle color [29]. The frozen storage's influence on the $a^{*}$ value of muscle has been reported [29].

The increase in $b^{*}$ values of the fish fillet was observed after 8 weeks of storage $(p<0.05)$. A positive correlation between lipid oxidation (TBARS) and yellow color $\left(b^{*}\right)$ formation was found in the Basa fillet. In addition, the first 8 weeks of storage, the gradual increase in the $b^{*}$ value of the fish sample correlated well with the slow increase in TBARS values (Figure 1). Aldehydes, ketones, and carbonyl compounds, products from the oxidation of unsaturated fatty acids, can react with free amino groups in protein. These reactions lead to discoloration and the production of unpleasant odors [30, 31]. Fish quality deteriorations, including lipid oxidation and discoloration, induced by frozen storage have been reported [25, 32, 33]. 


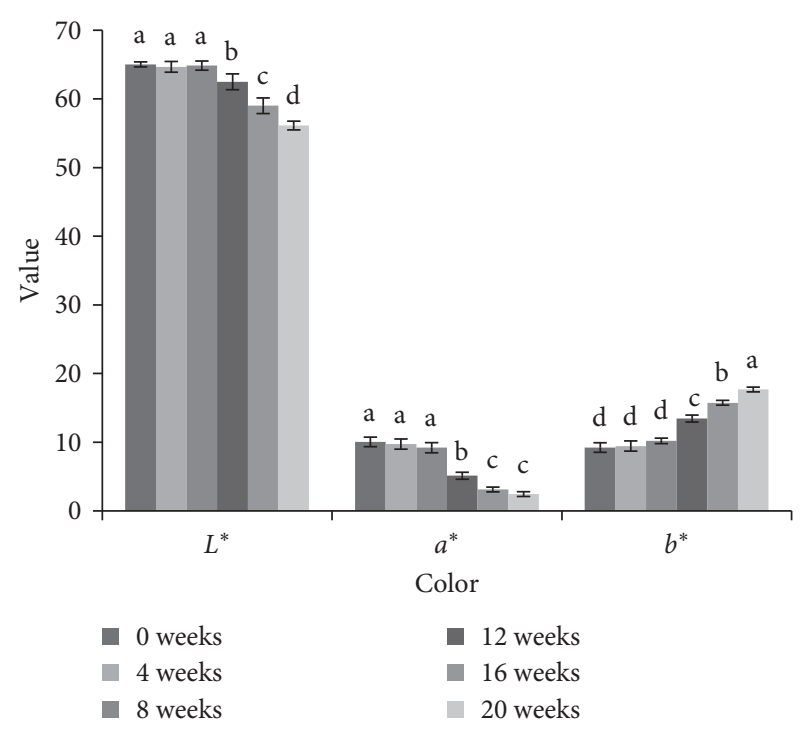

FIgURE 2: Changes in colors of the Basa fish fillet during frozen storage at $-20^{\circ} \mathrm{C}$ for 20 weeks. Bars represent standard deviation from triplicate determinations. The different letters on the bars within the same color indicate significant differences $(p<0.05)$.

3.3. Changes in Surface Hydrophobicity. Changes in surface hydrophobicity (SoANS) of NAM extracted from the Basa fillet subjected to frozen storage are shown in Figure 3. Generally, the slow increases in the SoANS of the Basa fillet during the first 8 weeks of storage were found $(p<0.05)$ (Figure 3). Thereafter, the marked increase in SoANS of the fish fillet up to 20 weeks of storage was observed $(p<0.05)$. The hydrophilic (polar) residues are generally exposed to water, while the hydrophobic (nonpolar) groups are localized in the molecules. An increase in surface hydrophobicity possibly resulted from structural alterations of proteins induced by frozen storage [7]. Benjakul and Sutthipan [6] reported an increase in the SoANS of natural actomyosin extracted from crab muscle during 8 weeks of frozen storage. The increase in surface hydrophobicity of frozen the Basa fillet was in agreement with other studies that showed an increased surface hydrophobicity as frozen storage time increased $[4,34]$. In addition, some studies also revealed that the increased protein oxidation, such as increasing of surface hydrophobicity, was coincidental with the increased lipid oxidation $[35,36]$, suggesting that protein structural changes might be a result of the reaction between functional groups of proteins and oxidation products of polyunsaturated fatty acids [37].

\subsection{Changes in Sulfhydryl Group and Disulfide Bond} Contents. Changes in sulfhydryl content and disulfide bond content of NAM extracted from the Basa fillet during frozen storage for 20 weeks are depicted in Figures 4(a) and 4(b). Generally, the gradual decrease in sulfhydryl group content of fish samples during the first 8 weeks was observed $(p<0.05)$ (Figure 4(a)). Thereafter, the marked decrease in the sulfhydryl group content was noticeable $(p<0.05)$. Myosin contains 42 sulfhydryl groups [20]. These reactive sulfhydryl groups are

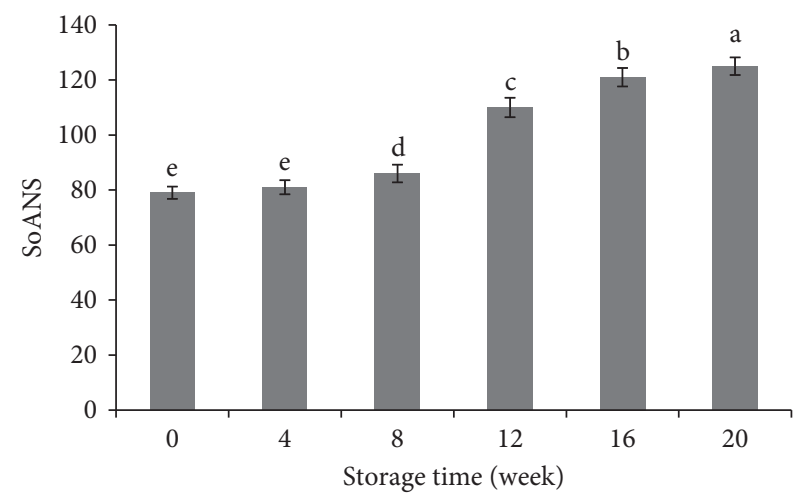

FIgURE 3: Changes in surface hydrophobic content of NAM extracted from the Basa fish fillet during frozen storage at $-20^{\circ} \mathrm{C}$ for 20 weeks. Bars represent standard deviation from triplicate determinations. The different letters on the bars indicate significant differences $(p<0.05)$.

susceptible to oxidation, especially during frozen storage [20]. The decrease in sulfhydryl group content was due to either the oxidation of sulfhydryl, disulfide interchanges, or the formation of hydrogen and hydrophobic bonds, which masked the reactive sulfhydryl structure of actomyosin molecules [6]. The decreases of total sulfhydryl groups of crab meat [6] and some fish species including croaker, lizardfish, threadfin bream, and bigeye snapper [38] during frozen storage were reported.

Disulfide bond formation was observed throughout the frozen storage (Figure 4(b)). The gradual increase in disulfide bond content was observed in fish samples during the first 8 weeks of storage (Figure 4(b)). Thereafter, marked increase in disulfide bond content was observed $(p<0.05)$. The increase in disulfide bond content correlates with the decrease in sulfhydryl content (Figure 4(a)). This result suggests that the freezing process may have induced the exposure of sulfhydryl groups, which were further oxidized to disulfide bonds. Conversion of sulfhydryl groups into disulfides and other oxidized species can be due to radicalmediated oxidation of protein [39]. Decreases in sulfhydryl group content of common carp (Cyprinus carpio) surimi as influenced by frozen storage have been reported [34].

3.5. Changes in $\mathrm{Ca}^{2+}$-ATPase Activity. The $\mathrm{Ca}^{2+}$-ATPase activity of NAM extracted from the Basa fillet during frozen storage is shown in Figure 5. A decrease in $\mathrm{Ca}^{2+}$-ATPase activity of fish sample with increasing storage time was observed. Decreases in $\mathrm{Ca}^{2+}$-ATPase activity of the Basa fillet during frozen storage may be due to conformational changes and protein polymerization. A decline in the $\mathrm{Ca}^{2+}$-ATPase activity of fish samples during frozen storage indicated myosin denaturation, especially in the head region [20]. Myosin globular head is responsible for the ATPase activity [16]. Kobayashi and Park [4] reported that the $\mathrm{Ca}^{2+}$-ATPase activity of NAM extracted from frozen tilapia (Oreochromis niloticus) decreased when frozen storage time increased. Decreasing in $\mathrm{Ca}^{2+}$-ATPase activity of NAM extracted from the common carp (Cyprinus carpio) fillet during extended frozen storage was also reported [8]. The result correlates 


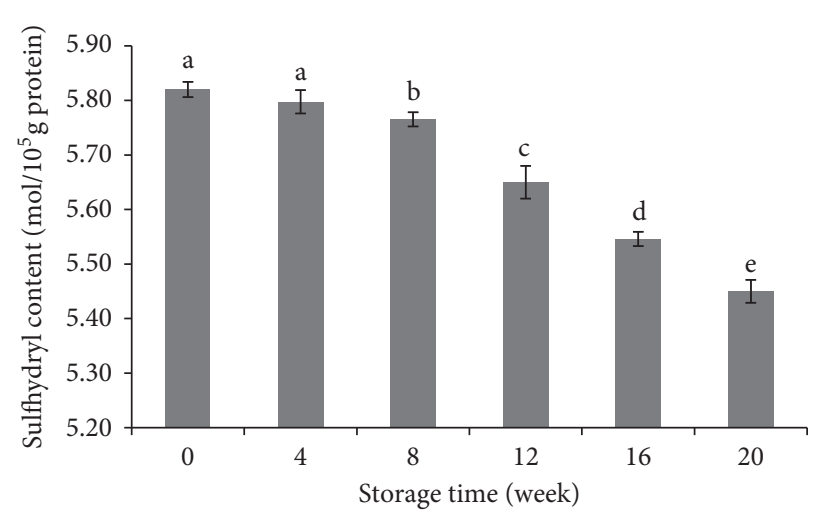

(a)

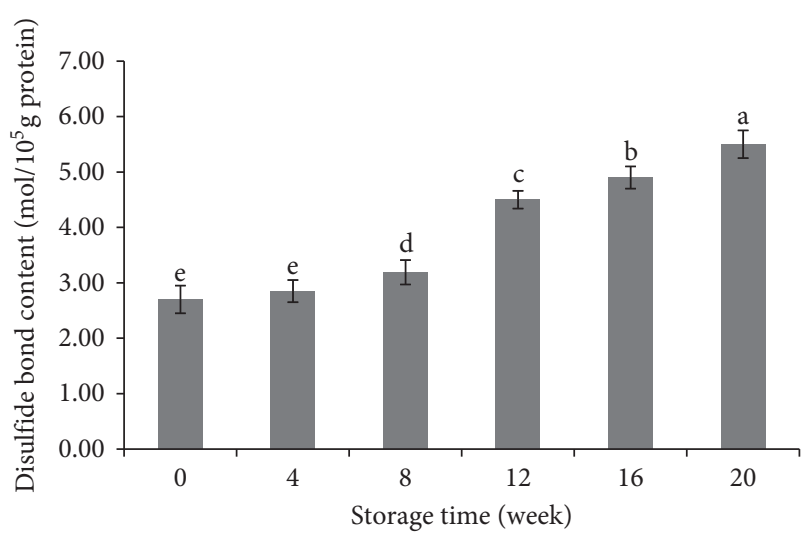

(b)

FIGURE 4: Changes in sulfhydryl (a) and disulfide bond (b) contents of NAM extracted from the Basa fish fillet during frozen storage at $-20^{\circ} \mathrm{C}$ for 20 weeks. Bars represent standard deviation from triplicate determinations. The different letters on the bars indicate significant differences $(p<0.05)$.

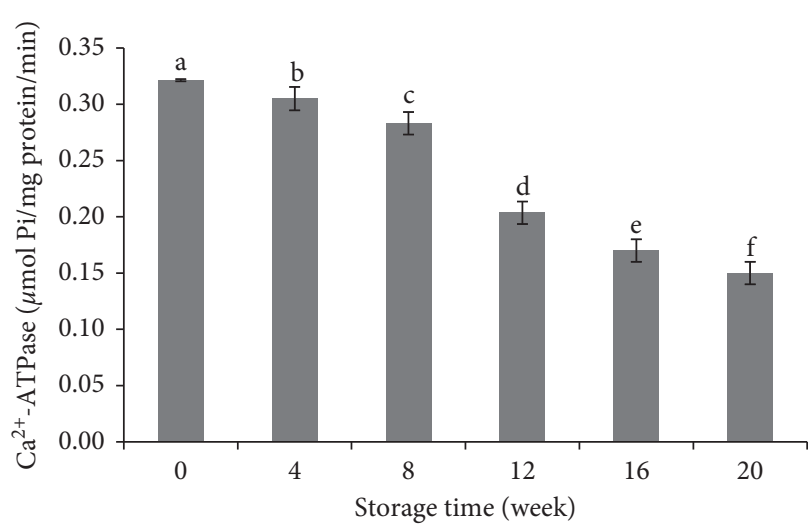

FIgURE 5: Changes in $\mathrm{Ca}^{2+}$-ATPase activities of NAM extracted from the Basa fish fillet during frozen storage at $-20^{\circ} \mathrm{C}$ for 20 weeks. Bars represent standard deviation from triplicate determinations. The different letters on the bars indicate significant differences $(p<0.05)$.

well with the increased surface hydrophobicity (Figure 3) and disulfide bond content (Figure 4(b)) of the Basa fillet with increasing storage times. Their results confirmed the denaturation and polymerization of fish protein as influenced by frozen storage.

3.6. Changes in Protein Solubility. Protein solubility in $0.6 \mathrm{M}$ $\mathrm{KCl}$ of the Basa fillet during frozen storage is shown in Figure 6. Gradual decreases in protein solubility of fish samples during the first 8 weeks were observed (Figure 6). After that the sharp decrease in protein solubility was found. The decreased solubility of the fish fillet during frozen storage was in accordance with the decreased sulfhydryl group content (Figure $4(\mathrm{a})$ ) and the $\mathrm{Ca}^{2+}$-ATPase activity (Figure 5) as well as the increased SoANS (Figure 3) and disulfide bond content (Figure 4(b)). The decrease in protein solubility is used as an indicator of protein denaturation. Decreases in solubility might be caused by protein aggregation during frozen storage or the freeze-thaw process [40].

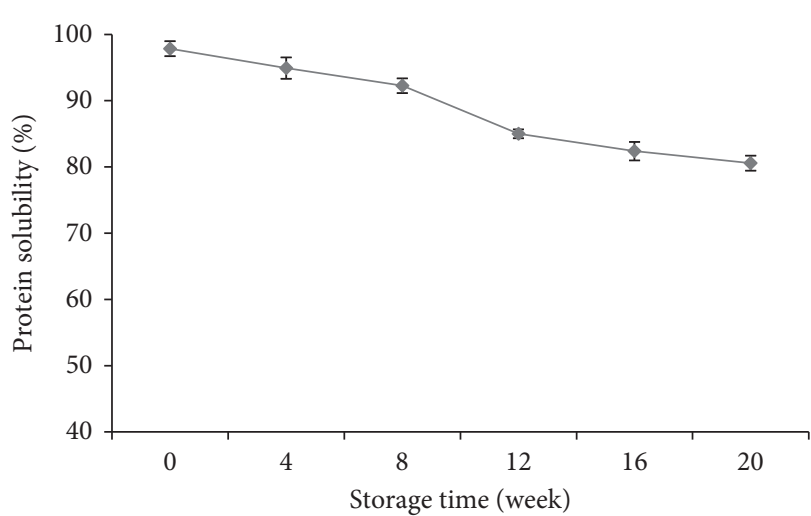

FIgURE 6: Changes in protein solubility of the Basa fish fillet during frozen storage at $-20^{\circ} \mathrm{C}$ for 20 weeks. Bars represent standard deviation from triplicate determinations.

Formation of disulfide bonds and hydrophobic interaction during frozen storage was associated with protein aggregation [41]. The decrease in protein solubility of common carp surimi during extended frozen storage was also reported [34]. Changes in the protein structure and functional properties, such as protein polymerization and loss of solubility, caused by oxidation, have been revealed [42]. Apart from protein oxidation, increase in lipid oxidation (Figure 1) was also correlated with protein solubility. Lipid degradation products are also capable of cross-linking polypeptides and thus are responsible for the generation of insoluble protein aggregates [43]. This possibly resulted in the loss in solubility of protein, especially when the storage time increased. Saeed and Howell [44] also reported the deleterious effect of lipid oxidation products on protein structure and function of frozen fatty fish.

3.7. Changes in Shear Force. Shear force of the Basa fillet during frozen storage for 20 weeks is shown in Figure 7. Generally, no changes in shear force of fish samples during the first 8 weeks of storage were observed. Thereafter, shear 


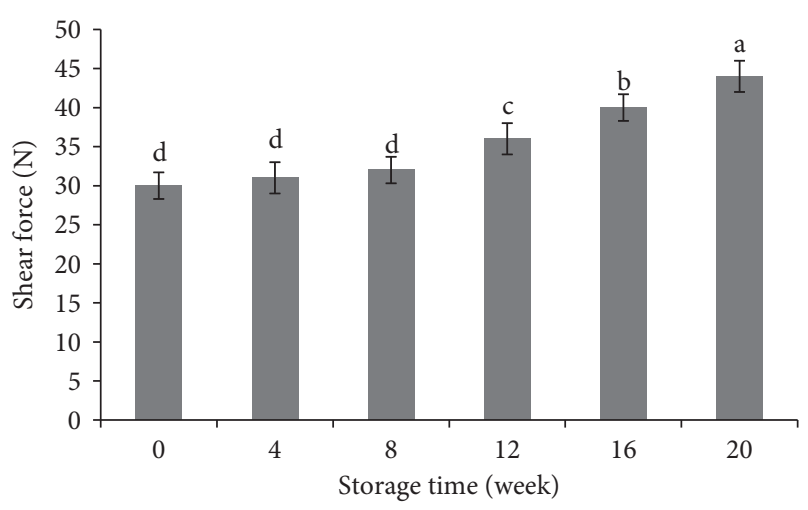

FIgURE 7: Changes in shear force of the Basa fish fillet during frozen storage at $-20^{\circ} \mathrm{C}$ for 20 weeks. Bars represent standard deviation from six determinations. The different letters on the bars indicate significant differences $(p<0.05)$.

force of fish samples increased markedly $(p<0.05)$. It was postulated that the more compact muscle fibers might be formed with increasing frozen time. This was related with the decreased protein solubility (Figure 6). When the water was removed from muscle as induced by freezing, the muscle fibrils became more concentrated, thereby resulting in higher aggregation [41]. Those aggregates led to the tougher texture as shown by the increased shear force. Freezing produced hardening of gels due to partial dehydration caused by ice crystal formation was also reported [45].

\section{Conclusion}

Basa fillets were susceptible to lipid oxidation and protein oxidation during extended frozen storage. The increase in yellow discoloration $\left(b^{*}\right)$ of the fish fillet was correlated well with increase in TBARS value. The lipid oxidation might be associated with the discoloration and tough texture of fish muscle. Therefore, frozen storage at $-20^{\circ} \mathrm{C}$ affected the qualities of the Basa fillet, especially after 8 weeks of storage. These data could be useful for the appropriate postharvest management of frozen-stored Basa fish meat for human consumption and food industry.

\section{Data Availability}

The data used to support the findings of this study are available from the corresponding author upon request.

\section{Conflicts of Interest}

The authors declare that there are no conflicts of interest regarding the publication of this paper.

\section{Acknowledgments}

The authors would like to thank National Research Council of Thailand for financial support. Ubon Ratchathani Rajabhat University is also acknowledged.

\section{References}

[1] E. Orban, T. Nevigato, G. Di Lena et al., "New trends in the seafood market. Sutchi catfish (Pangasius hypophthalmus) fillets from Vietnam: nutritional quality and safety aspects," Food Chemistry, vol. 110, no. 2, pp. 383-389, 2008.

[2] P. Thammapat, P. Raviyan, and S. Siriamornpun, "Proximate and fatty acids composition of the muscles and viscera of Asian catfish (Pangasius bocourti)," Food Chemistry, vol. 122, no. 1, pp. 223-227, 2010.

[3] D. Wang and Y.-H. P. Hsieh, "The use of imported pangasius fish in local restaurants," Food Control, vol. 65, pp. 136-142, 2016.

[4] Y. Kobayashi and J. W. Park, "Biochemical and physical characterizations of fish protein isolate and surimi prepared from fresh and frozen whole fish," $L W T$, vol. 77, pp. 200-207, 2017.

[5] Q. Liu, B. Kong, J. Han, Q. Chen, and X. He, "Effects of superchilling and cryoprotectants on the quality of common carp (Cyprinus carpio) surimi: microbial growth, oxidation, and physiochemical properties," LWT - Food Science and Technology, vol. 57, no. 1, pp. 165-171, 2014.

[6] S. Benjakul and N. Sutthipan, "Muscle changes in hard and soft shell crabs during frozen storage," LWT - Food Science and Technology, vol. 42, no. 3, pp. 723-729, 2009.

[7] A. Thanonkaew, S. Benjakul, W. Visessanguan, and E. A. Decker, "The effect of antioxidants on the quality changes of cuttlefish (Sepia pharaonis) muscle during frozen storage," LWT - Food Science and Technology, vol. 41, no. 1, pp. 161-169, 2008.

[8] C. Kong, H. Wang, D. Li et al., "Quality changes and predictive models of radial basis function neural networks for brined common carp (Cyprinus carpio) fillets during frozen storage," Food Chemistry, vol. 201, pp. 327-333, 2016.

[9] L. Shi, T. Yang, G. Xiong et al., "Influence of frozen storage temperature on the microstructures and physicochemical properties of pre-frozen perch (Micropterus salmoides)," LWT, vol. 92, pp. 471-476, 2018.

[10] A. S. Logan, U. Nienaber, and X. S. Pan, Lipid Oxidation: Challenges in Food Systems, Elsevier, New York, NY, USA, 2015.

[11] I. Undeland, "Oxidative stability of seafood," in Oxidative Stability and Shelf Life of Foods Containing Oils and Fats, pp. 391-460, Academic Press, New York, NY, USA, 2016.

[12] E. A. Foegeding, T. C. Lanier, and H. O. Hultin, "Food Chemistry," in Characteristics of Edible Muscle Tissue, pp. 875-942, Marcel Dekker, Inc., New York, NY, USA, 3rd edition, 1996.

[13] S. Rawdkuen, A. Jongjareonrak, S. Benjakul, and S. Chaijan, "Discoloration and lipid deterioration of farmed giant catfish (Pangasianodon gigas) muscle during refrigerated storage," Journal of Food Science, vol. 73, no. 3, pp. C179-C184, 2008.

[14] S. Kunnath, M. Lekshmi, M. K. Chouksey, N. Kannuchamy, and V. Gudipati, "Textural quality and oxidative stability of restructured pangasius mince: effect of protein substrates mediated by transglutaminase," Journal of Food Science and Technology, vol. 52, no. 1, pp. 351-358, 2015.

[15] J. A. Buege and S. D. Aust, "Microsomal lipid peroxidation," in Methods in Enzymology, vol. 52, pp. 302-310, Academic Press, New York, NY, USA, 1978.

[16] S. Benjakul, T. A. Seymour, M. T. Morrissey, and H. An, "Physicochemical changes in Pacific whiting muscle proteins during iced storage," Journal of Food Science, vol. 62, no. 4, pp. 729-733, 1997. 
[17] G. L. Ellman, "Tissue sulfhydryl groups," Archives of Biochemistry and Biophysics, vol. 82, no. 1, pp. 70-77, 1959.

[18] T. W. Thannhauser, Y. Konishi, and H. A. Scheraga, "Analysis for disulfide bonds in peptides and proteins," in Methods in Enzymology, vol. 143, pp. 115-119, Academic Press, New York, NY, USA, 1987.

[19] C. H. Fiske and Y. Subbarow, "The colorimetric determination of phosphorus," Journal of Biological Chemistry, vol. 66, no. 2, pp. 375-400, 1925.

[20] S. Benjakul and F. Bauer, "Physicochemical and enzymatic changes of cod muscle proteins subjected to different freeze-thaw cycles," Journal of the Science of Food and Agriculture, vol. 80, no. 8, pp. 1143-1150, 2000.

[21] H. W. Robinson and C. G. Hogden, "The biuret reaction in the determination of serum proteins," Journal of Biological Chemistry, vol. 135, no. 2, p. 707, 1940.

[22] J. M. E. Brauer, J. A. S. Leyva, L. B. Alvarado, and O. R. Sández, "Effect of dietary protein on muscle collagen, collagenase and shear force of farmed white shrimp (Litopenaeus vannamei)," European Food Research and Technology, vol. 217, no. 4, pp. 277-280, 2003.

[23] R. G. D. Steel and J. H. Torrie, Principles and Procedures of Statistics: A Biometrical Approach, McGraw-Hill, New York, NY, USA, 1980.

[24] Y. Thiansilakul, S. Benjakul, E. W. Grunwald, and M. P. Richards, "Retardation of myoglobin and haemoglobinmediated lipid oxidation in washed bighead carp by phenolic compounds," Food Chemistry, vol. 134, no. 2, pp. 789-796, 2012.

[25] I. Aydin and N. Gokoglu, "Effects of temperature and time of freezing on lipid oxidation in anchovy (Engraulis encrasicholus) during frozen storage," European Journal of Lipid Science and Technology, vol. 116, no. 8, pp. 996-1001, 2014.

[26] S. Benjakul and F. Bauer, "Biochemical and physicochemical changes in catfish (Silurus glanis Linne) muscle as influenced by different freeze-thaw cycles," Food Chemistry, vol. 72, no. 2, pp. 207-217, 2001.

[27] Y. Thiansilakul, S. Benjakul, and M. P. Richards, "Changes in heme proteins and lipids associated with off-odour of seabass (Lates calcarifer) and red tilapia (Oreochromis mossambicus $\times$ O. niloticus) during iced storage," Food Chemistry, vol. 121, no. 4, pp. 1109-1119, 2010.

[28] S. Benjakul, W. Visessanguan, C. Thongkaew, and M. Tanaka, "Effect of frozen storage on chemical and gel-forming properties of fish commonly used for surimi production in Thailand," Food Hydrocolloids, vol. 19, no. 2, pp. 197-207, 2005.

[29] V. Alonso, E. Muela, J. Tenas, J. B. Calanche, P. Roncalés, and J. A. Beltrán, "Changes in physicochemical properties and fatty acid composition of pork following long-term frozen storage," European Food Research and Technology, vol. 242, no. 12, pp. 2119-2127, 2016.

[30] J. Pokorny, "Browning from lipid-protein interactions," Progress in Food and Nutrition Science, vol. 5, pp. 421-428, 1981.

[31] E. Wsowicz, A. Gramza, M. Hês et al., "Oxidation of lipids in food," Polish Journal of Food and Nutrition Sciences, vol. 13, pp. 87-100, 2004.

[32] A. Mousakhani-Ganjeh, N. Hamdami, and N. Soltanizadeh, "Impact of high voltage electric field thawing on the quality of frozen tuna fish (Thunnus albacares)," Journal of Food Engineering, vol. 156, pp. 39-44, 2015.

[33] A. Mousakhani-Ganjeh, N. Hamdami, and N. Soltanizadeh, "Effect of high voltage electrostatic field thawing on the lipid oxidation of frozen tuna fish (Thunnus albacares), Innovative Food Science \& Emerging Technologies, vol. 36, pp. 42-47, 2016.

[34] Y. Li, B. Kong, X. Xia, Q. Liu, and P. Li, "Inhibition of frozen storage-induced oxidation and structural changes in myofibril of common carp (Cyprinus carpio) surimi by cryoprotectant and hydrolysed whey protein addition," International Journal of Food Science \& Technology, vol. 48, no. 9, pp. 1916-1923, 2013.

[35] B. H. Kong, Y. Guo, X. Xia, Q. Liu, Y. Li, and H. Chen, "Cryoprotectants reduce protein oxidation and structure deterioration induced by freeze-thaw cycles in common carp (Cyprinus carpio) Surimi," Food Biophysics, vol. 8, no. 2, pp. 104-111, 2013.

[36] X. Xia, B. Kong, Q. Liu, and J. Liu, "Physicochemical change and protein oxidation in porcine longissimus dorsi as influenced by different freeze-thaw cycles," Meat Science, vol. 83, no. 2, pp. 239-245, 2009.

[37] B. Tokur and K. Korkmaz, "The effects of an iron-catalyzed oxidation system on lipids and proteins of dark muscle fish," Food Chemistry, vol. 104, no. 2, pp. 754-760, 2007.

[38] S. Benjakul, W. Visessanguan, C. Thongkaew, and M. Tanaka, "Comparative study on physicochemical changes of muscle proteins from some tropical fish during frozen storage," Food Research International, vol. 36, no. 8, pp. 787-795, 2003.

[39] R. T. Dean, S. Fu, R. Stocker, and M. J. Davies, "Biochemistry and pathology of radical-mediated protein oxidation," Biochemistry Journal, vol. 324, no. 1, pp. 1-18, 1997.

[40] I. W. Y. Cheung, A. M. Liceaga, and E. C. Y. Li-Chan, "Pacific hake (Merluccius productus) hydrolysates as cryoprotective agents in frozen Pacific cod fillet mince," Journal of Food Science, vol. 74, no. 8, pp. C588-C594, 2009.

[41] P. Kingwascharapong and S. Benjakul, "Effect of phosphate and bicarbonate replacers on quality changes of raw and cooked Pacific white shrimp as influenced by the repeated freeze-thawing," International Journal of Refrigeration, vol. 67, pp. 345-354, 2016.

[42] T. Ooizumi and Y. L. Xiong, "Biochemical susceptibility of myosin in chicken myofibrils subjected to hydroxyl radical oxidizing systems," Journal of Agricultural and Food Chemistry, vol. 52, no. 13, pp. 4303-4307, 2004.

[43] H. Buttkus, "Accelerated denaturation of myosin in frozen solution," Journal of Food Science, vol. 35, no. 5, pp. 558-562, 1970.

[44] S. Saeed and N. K. Howell, "Effect of lipid oxidation and frozen storage on muscle proteins of Atlantic mackerel (Scomber scombrus)," Journal of the Science of Food and Agriculture, vol. 82, no. 5, pp. 579-586, 2002.

[45] B. Solo-de-Zaldívar, B. Herranz, A. J. Borderías, and C. A. Tovar, "Effect of freezing and frozen storage on restructured FISH prototypes made with glucomannan and FISH mince," Food Hydrocolloids, vol. 41, pp. 233-240, 2014. 

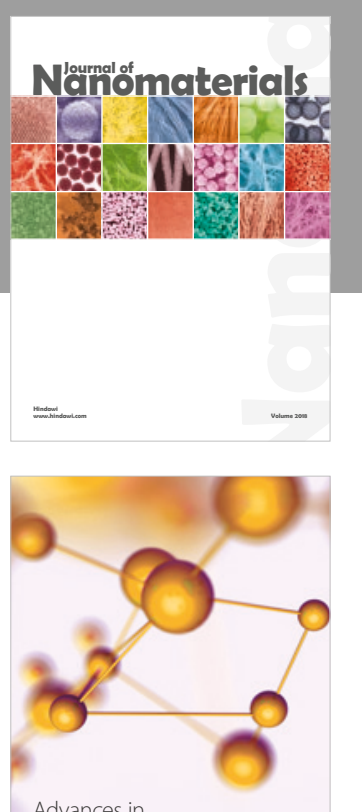

Physical Chemistry
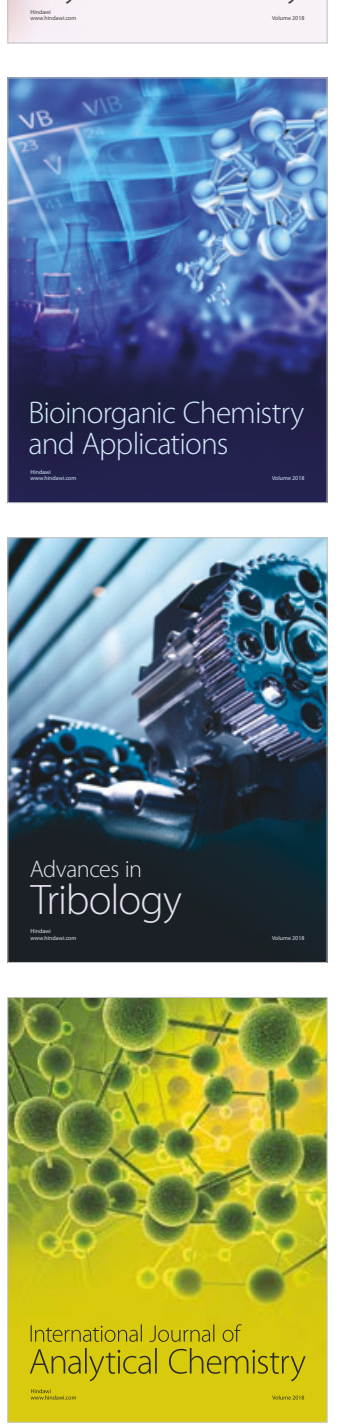

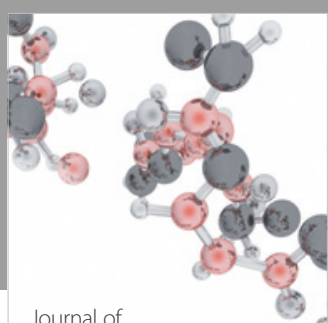

Analytical Methods

in Chemistry

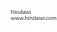

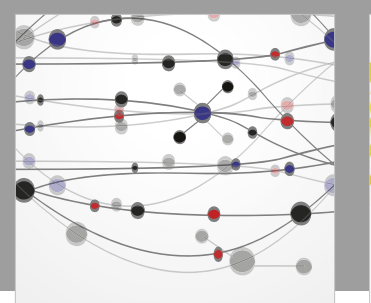

The Scientific World Journal

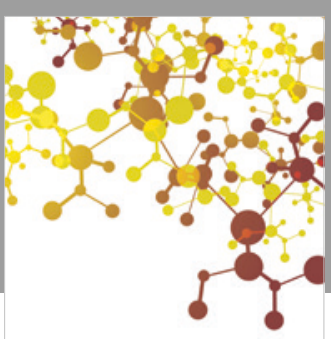

Journal of

Applied Chemistry
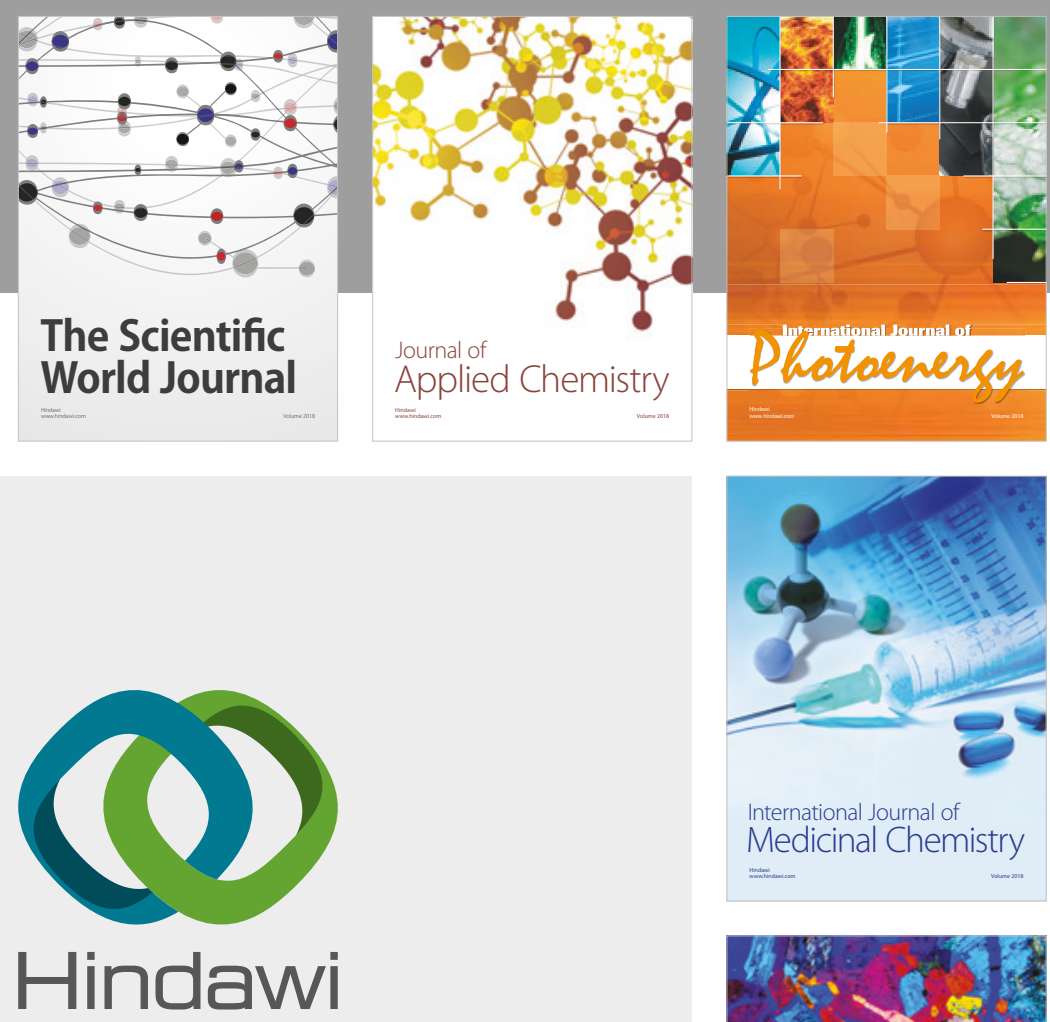

Submit your manuscripts at

www.hindawi.com
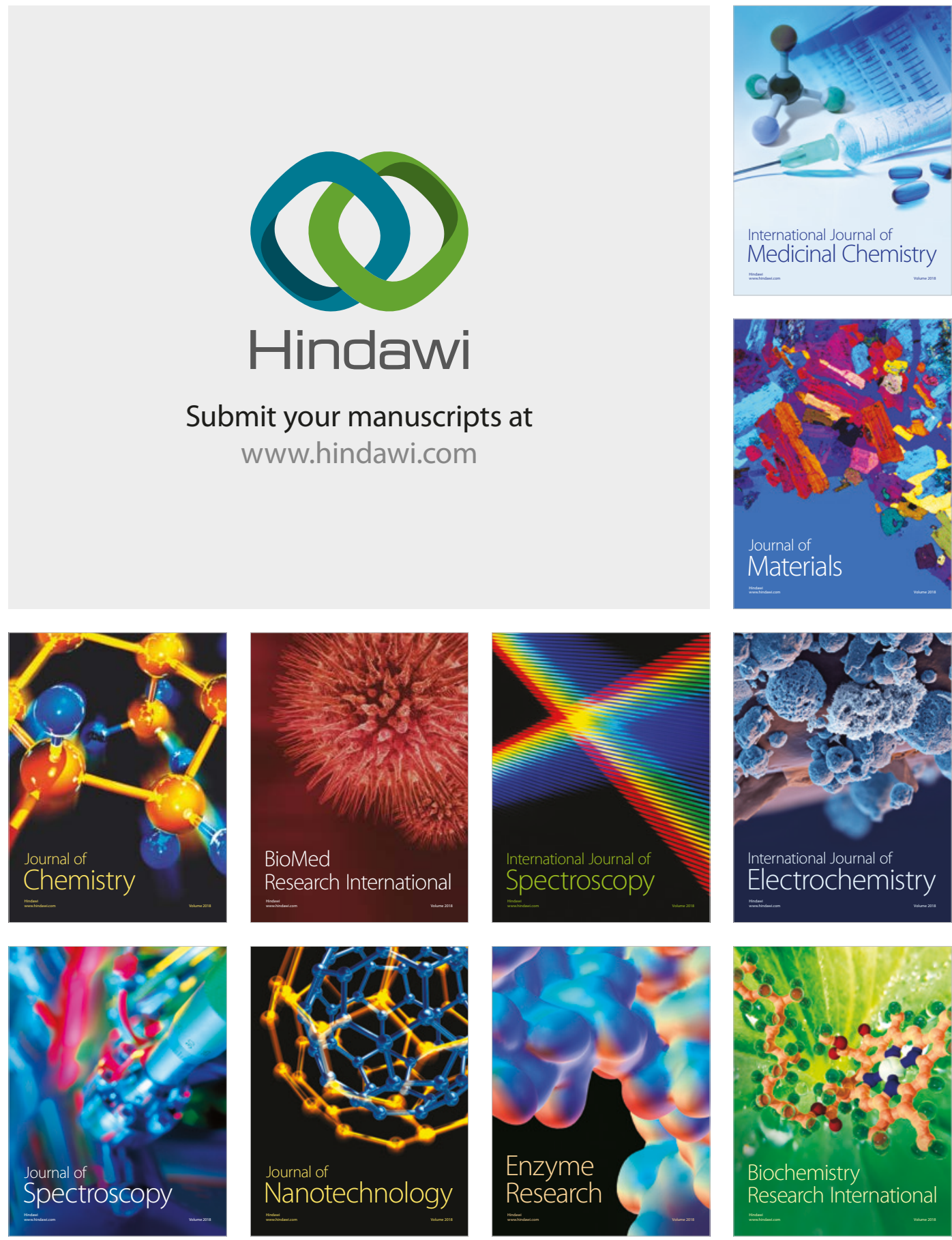
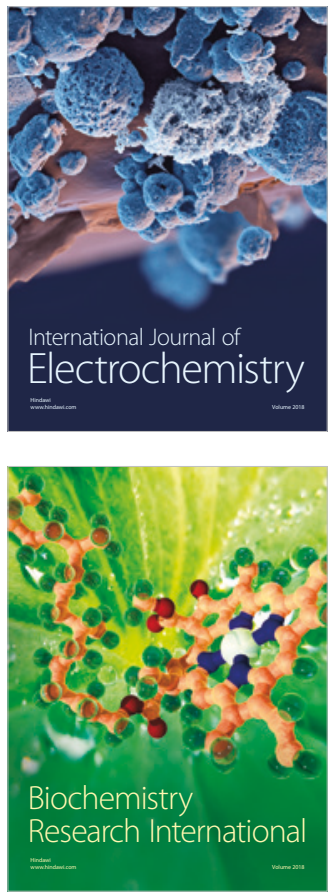